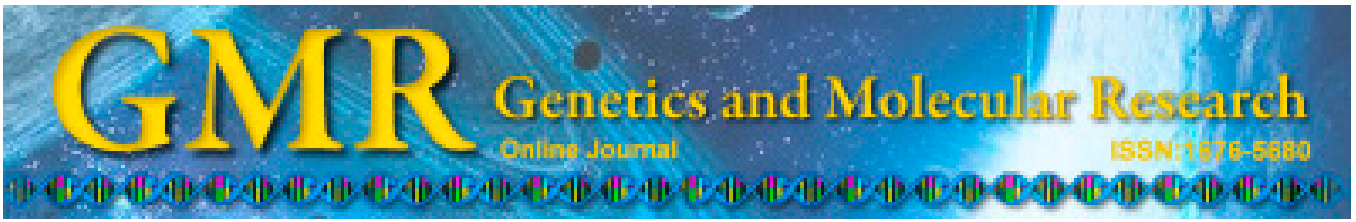

\title{
DNA barcoding and phylogenetic relationships in Timaliidae
}

\author{
Z.H. Huang and D.H. Ke \\ School of Life Sciences, Jinggangshan University, Ji’an, Jiangxi Province, \\ China \\ Corresponding author: Z.H. Huang \\ E-mail: hzhow@163.com
}

Genet. Mol. Res. 14 (2): 5943-5949 (2015)

Received August 14, 2014

Accepted January 21, 2015

Published June 1, 2015

DOI http://dx.doi.org/10.4238/2015.June.1.11

\begin{abstract}
The Timaliidae, a diverse family of oscine passerine birds, has long been a subject of debate regarding its phylogeny. The mitochondrial cytochrome c oxidase subunit I (COI) gene has been used as a powerful marker for identification and phylogenetic studies of animal species. In the present study, we analyzed the COI barcodes of 71 species from 21 genera belonging to the family Timaliidae. Every bird species possessed a barcode distinct from that of other bird species. Kimura two-parameter (K2P) distances were calculated between barcodes. The average genetic distance between species was 18 times higher than the average genetic distance within species. The neighborjoining method was used to construct a phylogenetic tree and all the species could be discriminated by their distinct clades within the phylogenetic tree. The results indicate that some currently recognized babbler genera might not be monophyletic, with the COI gene data supporting the hypothesis of polyphyly for Garrulax, Alcippe, and Minla. Thus, DNA barcoding is an effective molecular tool for Timaliidae species identification and phylogenetic inference.
\end{abstract}

Key words: DNA barcoding; Cytochrome c oxidase I; Timaliidae; Phylogenetic relationship; Polyphyly 


\section{INTRODUCTION}

The avian family Timaliidae, generally known as the babblers, is a species rich and morphologically diverse component of African and Asian tropical forests (Moyle et al., 2012). Babblers display great diversity in size, bill shape, and plumage coloration, and perhaps the most reliable character that unites babblers is their high sociability (Cibois, 2003). This group is not strongly migratory, and most species have short rounded wings and a weak flight. Most babbler species clump together when perched during the day and while roosting at night, and mutual preening is observed in many species (Simmons, 1963).

The systematics of Timaliidae has long been contended (e.g., Delacour, 1946, 1950; Cibois 2003; Gelang et al., 2009; Moyle et al., 2012). Delacour $(1946,1950)$ conducted the main systematic review of the group; defining 252 species in 47 genera. However, the molecular phylogeny challenges the traditional classification of the Timaliidae (e.g., Cibois, 2003; Luo et al., 2009). Sibley and Ahlquist (1990) first attempted to clarify the phylogeny of the Timaliidae using molecular data and recent molecular phylogenetic research has begun to shed light on the systematic relationships in babblers (Cibois, 2003; Luo et al., 2009; Gelang et al., 2009; Dong et al., 2010; Moyle et al., 2012). However, the relationships within Timaliidae still remain controversial, and the non-monophyly of some genera of Timaliidae has been questioned by previous studies (e.g., Cibois, 2003; Luo et al., 2009; Dong et al., 2010).

A certain fragment of the mitochondrial DNA (mtDNA) gene, coding for a subunit of the enzyme cytochrome oxidase (COI), has become widely known and used as "the DNA barcode" for the identification of many animal species (e.g., Hebert et al., 2003a,b, 2004a; Cai et al., 2010; Breman et al., 2013). A previous study of 260 birds from North America revealed that most species could be properly discriminated using COI sequences (Hebert et al., 2004a). In addition, COI has been used successfully in determining the phylogeny of many animal groups, especially in birds (e.g., Hebert et al., 2004b; Yoo et al., 2006; Kerr et al., 2007, 2009; Johnsen et al., 2010; Huang and Ke, 2014). Since this technique is based on molecular-level variation, it offers greater accuracy and authenticity compared to the more subjective plumage-based phylogeny of birds (Arif et al., 2011).

To date, DNA barcoding studies on Timaliidae birds remain limited. In the present study, we examined the 615 bp COI gene of Timaliidae birds and then conducted phylogenetic analyses within Timaliidae based on these sequences. Our main aim was to clarify the relationships among the babblers and to demonstrate that the COI gene can be an efficient marker for identification of babblers. Moreover, the polyphyly of some genera of Timaliidae was examined.

\section{MATERIAL AND METHODS}

One hundred and thirty seven COI sequences were obtained from GenBank, and 71 species from 21 genera belonging to the family Timaliidae were analyzed (Table S1).

Sequences were aligned using the Clustal X procedure (Thompson et al., 1997) and a total of $615 \mathrm{bp}$ of the mtDNA COI gene were analyzed. DnaSP v5.0 (Librado and Rozas, 2009) was used to define the variable sites and sequence divergence among species and genera was calculated using the Kimura two-parameter (K2P, Kimura, 1980) distance model using MEGA 6.0 (Tamura et al., 2013). The neighbor-joining method (Saitou and Nei, 1987) was used to reconstruct the phylogenetic tree based on the K2P model using MEGA 6.0. Node support was assessed using the bootstrap method (Felsenstein, 1985). 


\section{RESULTS}

\section{Barcoding analysis}

Two hundred and forty two variable sites were identified, of which 234 were parsimoniously informative (38.05\% of the entire sequence). All of the bird species had distinct COI sequences. The average nucleotide composition was $23.33 \% \mathrm{~T}, 33.08 \% \mathrm{C}, 26.95 \% \mathrm{~A}$, and $16.64 \% \mathrm{G}$.

K2P genetic distances within-species had a small range (0 to $5.15 \%$ ), with more than $80.95 \%$ of the observations below $1 \%$ genetic distance (Figure 1). Pairwise comparisons among species were distributed from $1.57 \%$ (between Actinodura waldeni and Actinodura souliei) to $20.73 \%$ (between Rimator malacoptilus and Spelaeornis chocolatinus), with most of the comparisons observed between 10-18\% K2P genetic distance, up to 92.23\% (Figure 1). The average difference in the COI sequence between species (14.02\%) was 18 -fold higher than the average difference within-species $(0.76 \%)$.
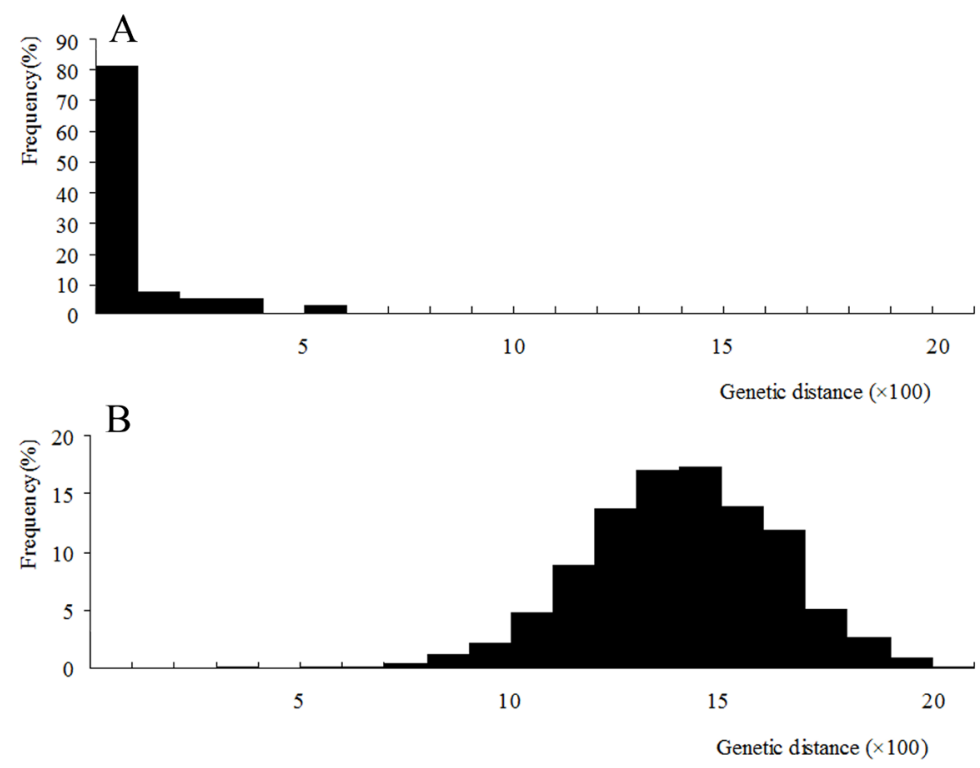

Figure 1. Frequency distribution of genetic distances within (A) and among (B) species of Timaliidae.

\section{Phylogenetic relationships}

The neighbor-joining method was used to reconstruct the phylogenetic tree based on the K2P model. All the species could be discriminated by their distinct clades in the phylogenetic tree (Figure S1). In most cases, the phylogenetic tree showed shallow intraspecific and deep interspecific divergence. Four species of Alcippe were the first to split from the Timaliidae lineage (Figure S1) and the second clade included Macronous and Stachyris.

The phylogenetic tree did not group some genera of Timaliidae into a single clade. The genus Minla was divided into two clades: M. strigula + M. cyanouroptera and M. ignotincta. The genus Alcippe was divided into three clades: A. castaneceps + A. brunnea $+A$. 
cinerea + A. rufogularis, A. poioicephala + A. morrisonia, and A. vinipectus $+A$. cinereiceps . The genus Garrulax was split into two disjunctive clades: G. virgatus + G. lineatus + G. subunicolor + G. erythrocephalus + G. formosus $+G$. milnei + G. affinis + G. morrisonianus + G. elliotii and G. sannio + G. perspicillatus + G. cineraceus + G. ocellatus + G. maximus + G. lunulatus + G. monileger + G. leucolophus + G. canorus + G. chinensis + G. nuchalis. Species within the genus Babax were shown to be the sister group to the second clade of Garrulax with a relatively low support.

\section{DISCUSSION}

The effectiveness of the barcoding system has been repeatedly demonstrated by the identification of bird species (e.g., Yoo et al., 2006; Kerr et al., 2007; Lohman et al., 2009; Kerr et al., 2009; Johnsen et al., 2010; Park et al., 2011; Breman et al., 2013). These studies have confirmed a clear gap (the so-called barcoding gap) between intra- and interspecific K2P distance distributions (Breman et al., 2013). Hebert et al. (2004a) found the COI sequence variation between species was on average twenty times larger than that within species. Hebert et al. (2003a) proposed a "10X rule," which is a sequence threshold of 10 times the mean intraspecific variation for the group under study, to define species boundaries. Many studies support the fact that distance-based DNA barcoding provides sufficient information to identify and delineate a large majority of bird species, including Timaliidae, through pairwise comparisons. However, the rate of COI gene evolution is subject to variation in different clades of birds (Pereira and Baker, 2006). Therefore, it may be inappropriate to suggest a universal distance criterion for different species.

The results of this study clearly show the discriminative power of COI barcodes for the identification of Timaliidae species. Every babbler has a distinct COI sequence and COI analysis separated the different Timaliidae species into distinct branches. None of the species shared sequences or had overlapping clades with another species. However, not all parts of the topology in the phylogenetic tree were well supported, and COI analysis demonstrated that some currently recognized babbler genera may be polyphyletic, including Garrulax, Alcippe, and Minla.

\section{Garrulax}

Garrulax is the most diverse genus within Timaliidae (Dickinson, 2003). Berlioz (1930) revised the systematics of the laughingthrush and defined three species groups based on bill morphology, plumage coloration, and habitat characteristics. Sibley and Ahlquist (1990) considered Garrulax and Liocichla as representing the sibling clade for all other babblers based on DNA hybridization. Cibois (2003) revealed that the laughingthrushes may not be monophyletic and that Liocichla was distantly related to Garrulax. According to Cibois (2003), Garrulax grouped with Babax, Liocichla, Minla, Leiothrix, Heterophasia, and Turdoides. Recently, Luo et al. (2009) found that Garrulax species could split into two clades. Our results are consistent with those of Luo et al. (2009), with the COI gene analysis clearly demonstrating that species from Garrulax can be divided into two clades: one grouped with Babax, the other grouped with Actinodura, Minla, Liocichla, Heterophasia, Spelaeornis, and Leiothrix (Figure S1). The results from various studies provide support for the hypothesis of polyphyly for the laughingthrushes group. 


\section{Alcippe}

The genus Alcippe has long been treated as a single group by most taxonomists (Sibley and Monroe, 1990; Howard and Moore, 1991). However, in a recent molecular phylogenetic study, Cibois (2003) suggested that the fulvettas were polyphyletic. Pasquet et al. (2006) supported this hypothesis. However, Moyle et al. (2012) found six species from Alcippe formed a clade. Our results also indicate that the genus Alcippe is not monophyletic, with the COI gene analysis demonstrating that Alcippe is polyphyletic, with four species (A. rufogularis, A. cinerea, A. castaneceps, and A. brunnea) in one clade, two species ( $A$. poioicephala and $A$. morrisonia) in another clade, and two species (A. vinipectus and $A$. cinereiceps) in a third clade (Figure S1).

\section{Minla}

The systematics of the Minla species (ignotincta, strigula, cyanouroptera) have been controversial (Luo et al., 2009; Dong et al., 2010). Harrison (1986) placed M. cyanouroptera in the genus Leiothrix or in its monotypic genus Siva based on morphologic characteristics. While Cibois (2003) considered M. cyanouroptera to be closely related to Acinodura based on molecular data. However, Cibois (2003) pointed out that the position of $M$. ignotincta and M. strigula were not consistent in studies using different analytic methods, thus, taxonomic modifications must await further studies on the genus. Recently, researchers have suggested that the genus Minla can be split into three monotypic genera (Collar and Robson, 2007; Dong et al., 2010). However, our study indicates that the genus Minla can be divided into two clades: M. strigula + M. cyanouroptera grouping with Actinodura, and $M$. ignotincta grouping with Spelaeornis (Figure S1). Luo et al. (2009) also found strong support for the sister relationship between M. cyanouroptera and M. strigula, and M. ignotincta did not group with these. Our results support the genus Minla being split into two monophyletic clades rather than three clades.

In conclusion, the current study found that all the Timaliidae species have distinct COI sequences. Thus, DNA barcoding is an effective molecular tool for species identification and phylogenetic inference of Timaliidae. The COI gene analysis confirmed that some genera of Timaliidae were polyphyletic. However, to further resolve the phylogenetic relationships of Timaliidae, more taxon sampling as well as multiple nuclear markers are required for future studies.

\section{Conflicts of interest}

The authors declare no conflict of interest.

\section{ACKNOWLEDGMENTS}

Research supported by the National Natural Science Foundation of China (\#30960051 and \#31260088), Jiangxi Province Talent Project 555, Jiangxi Province Major Disciplines Academic Leaders (\#20133BCB22010), and the Natural Science Foundation of Jiangxi Province (\#20132BAB204022 and \#20152ACB21006). 


\section{Supplementary material}

\section{REFERENCES}

Arif IA, Khan HA, Shobrak M and Williams J (2011). Cytochrome c oxidase subunit I barcoding of the green bee-eater (Merops orientalis). Genet. Mol. Res. 10: 3992-3998.

Berlioz J (1930). Révision systématique du genre Garrulax Lesson. L'Oiseau 11: 128-159.

Breman FC, Jordaens K, Sonet G, Nagy ZT, et al. (2013). DNA barcoding and evolutionary relationships in Accipiter Brisson, 1760 (Aves, Falconiformes: Accipitridae) with a focus on African and Eurasian representatives. J. Ornithol. 154: 265-287.

Cai Y, Yue B, Jiang W, Xie S, et al. (2010). DNA barcoding on subsets of three families in Aves. Mitochondrial DNA 21: 132-137.

Cibois A (2003). Mitochondrial DNA phylogeny of babblers (Timaliidae). The Auk 120: 35-54.

Collar N and Robson C (2007). Family Timaliidae (Babblers). In: Handbook of the birds of the world - Volume 12. Picathartes to tits and chickadees (del Hoyo J, Elliott A and Christie DA, eds.). Lynx Edicions, Barcelona, 70-291.

Dai C, Chen K, Zhang R, Yang X, et al. (2010). Molecular phylogenetic analysis among species of Paridae, Remizidae and Aegithalos based on mtDNA sequences of COI and cyt b. Chin. Birds 1: 112-123.

Delacour J (1946). Les Timaliinés. L'Oiseau 16: 7-36.

Delacour J (1950). Les Timaliinés: Additions et modifications. L'Oiseau 20: 186-191.

Dickinson EC (2003). The Howard and Moore complete checklist of the birds of the birds of the world. 3rd edn. Christopher Helm Publishers, London.

Dong F, Li SH and Yang XJ (2010). Molecular systematics and diversification of the Asian scimitar babblers (Timaliidae, Aves) based on mitochondrial and nuclear DNA sequences. Mol. Phylogenet. Evol. 57: 1268-1275.

Felsenstein J (1985). Confidence limits on phylogenies: an approach using the bootstrap. Evolution 39: 783-791.

Gelang M, Cibois A, Pasquet E, Olsson U, et al. (2009). Phylogeny of babblers (Aves, Passeriformes): major lineages, family limits and classification. Zool. Scr. 38:225-236.

Harrison CJO (1986). A reassessment of the affinities of some small Oriental babblers Timaliidae. Forktail 1: 81-83.

Hebert PDN, Ratnasingham S and deWaard JR (2003a). Barcoding animal life: cytochrome c oxidase subunit 1 divergences among closely related species. Proc. R. Soc. B-Biol. Sci. 270: S96-99.

Hebert PDN, Cywinska A, Ball SL and deWaard JR. (2003b). Biological identifications through DNA barcodes. Proc. R. Soc. B-Biol. Sci. 270: 313-321.

Hebert PDN, Stoeckle MY, Zemlak TS and Francis CM (2004a). Identification of birds through DNA Barcodes. PLoS Biol. 2: e312.

Hebert PDN, Penton EH, Burns JM, Janzen DH, et al. (2004b). Ten species in one: DNA barcoding reveals cryptic species in the neotropical skipper butterfly Astraptes fulgerator. Proc. Natl. Acad. Sci. U.S.A. 101: 14812-14817.

Howard R and Moore A (1991). A Complete Checklist of the Birds of the World. 2nd edn. Academic Press, London.

Huang ZH and Ke DH (2014). DNA barcoding and evolutionary relationships of the Phasianidae family in China. Genet. Mol. Res. 13: 7411-7419.

Johnsen A, Rindal E, Ericson PGP, Zuccon D, et al. (2010). DNA barcoding of Scandinavian birds reveals divergent lineages in trans-Atlantic species. J. Ornithol. 151: 565-578.

Kerr KCR, Stoeckle MY, Dove CJ, Weigt LA, et al. (2007). Comprehensive DNA barcode coverage of North American birds. Mol. Ecol. Notes 7: 535-543.

Kerr KCR, Birks SM, Kalyakin MV, Red'kin YA, et al. (2009). Filling the gap-COI barcode resolution in eastern Palearctic birds. Front. Zool. 6: 29.

Kimura M. (1980). A simple method for estimating evolutionary rates of base substitutions through comparative studies of nucleotide sequences. J. Mol. Evol. 16: 111-120.

Librado P and Rozas J (2009). DnaSP v5: a software for comprehensive analysis of DNA polymorphism data. Bioinformatics 25: 1451-1452.

Lohman DJ, Prawiradiraga DM and Meier R (2009). Improved CO1 barcoding primers for Southeast Asian perching birds (Aves: Passeriformes). Mol. Ecol. Resour. 9: 37-40.

Luo X, Qu YH, Han LX, Li SH, et al. (2009). A phylogenetic analysis of laughingthrushes (Timaliidae: Garrulax) and allies based on mitochondrial and nuclear DNA sequences. Zool. Scr. 38: 9-22.

Moyle RG, Andersen MJ, Oliveros CH, Steinheimer FD, et al. (2012). Phylogeny and biogeography of the core babblers (Aves: Timaliidae). Syst. Biol. 61:631-51.

Park HY, Yoo HS, Jung G and Kim CB (2011). New DNA barcodes for identification of Korean birds. Genes Genom. 
33: 91-95.

Pasquet E, Bourdon E, Kalyakin MV and Cibois A (2006). The fulvettas (Alcippe, Timaliidae, Aves): a polyphyletic group. Zool. Scr. 35: 559-566.

Pereira SL and Baker AJ (2006). A molecular timescale for galliform birds accounting for uncertainty in time estimates and heterogeneity of rates of DNA substitutions across lineages and sites. Mol. Phylogenet. Evol. 38: 499-509.

Saitou N and Nei M (1987). The neighbor-joining method: a new method for reconstructing phylogenetic trees. Mol. Biol. Evol. 4: 406-425.

Schindel DE, Stoeckle MY, Milensky C, Trizna M, et al. (2011). Project description: DNA barcodes of bird species in the national museum of natural history, Smithsonian institution, USA. Zookeys 152: 87-92.

Shen YY, Liang L, Sun YB, Yue BS, et al. (2010). A mitogenomic perspective on the ancient, rapid radiation in the Galliformes with an emphasis on the Phasianidae. BMC Evol. Biol. 10: 132

Sibley CG and Ahlquist JE (1990). Phylogeny and classification of birds: a study in molecular evolution. Yale University Press, New Haven, Connecticut.

Sibley CG and Monroe BLJr (1990). Distribution and Taxonomy of Birds of the World. Yale University Press, New Haven, Connecticut.

Simmons KEL (1963). Some behaviour characters of the babblers Timaliidae. Avicultural Magazine 69: 183-193.

Tamura K, Stecher G, Peterson D, Filipski A, et al. (2013). MEGA6: Molecular evolutionary genetics analysis version 6.0. Mol. Biol. Evol. 30: 2725-2729.

Thompson JD, Gibson TJ, Plewniak F, Jeanmougin F, et al. (1997). The CLUSTAL_X windows interface: flexible strategies for multiple sequence alignment aided by quality analysis tools. Nucleic Acids Res. 25: 4876-4882.

Yoo HS, Eah JY, Kim JS, Kim YJ, et al. (2006). DNA barcoding Korean birds. Mol. Cells 22: 323-327. 